\title{
STUDIES IN FENTANYL-SUPPLEMENTED ANAESTHESIA: AWARENESS AND EFFECT OF NALOXONE ON EARLY POST-OPERATIVE RECOVERY
}

\author{
J.G. Purdell-Lewis, D.M. Blair and C.A. MCLeod
}

\begin{abstract}
Ninety-nine unselected patients were given a standardized general anaesthetic with fentanyl $1.5 \mu \mathrm{g} \cdot \mathrm{kg}^{-1}$ every 30 minutes and were randomly divided into three equal groups; Group I patients received naloxone $0.1 \mathrm{mg}$, Group II naloxone $0.2 \mathrm{mg}$ and Group III naloxone $0.4 \mathrm{mg}$ intravenously at the end of the operation and after the reversal of neuromuscular blockade. After naloxone the level of consciousness lightened and the response to stimulus increased: the changes were significant in all three groups and the actual changes were significantly greater in Groups II and III compared with Group I. In the Recovery Room there was no significant difference among the Groups for shivering, nausea, vomiting or pain. The incidence of operative awareness was one per cent and that of dreaming eight per cent and this was unrelated to naloxone dosage. Patient acceptance was high, seven patients not wanting this type of anaesthesia again due to (a) light premedication (inherent in the study design), two patients; (b) nausea and vomiting, four patients; and (c) slow awakening, one patient.
\end{abstract}

KeY WoRdS: ANAESTHETIC TeChNiques, Intravenous; fentanyl, awareness; RECOVERY: naloxone.

The use of fentanyl in balanced anaesthesia is enjoying an increasing vogue and a four-fold rise in fentanyl use was noted in the five-year period, 1974-1979.'

Post-anaesthetic respiratory inadequacy may be reversed with naloxone ${ }^{2-6}$ and the resultant cardiovascular effects have been reported in $\operatorname{man}^{6.7}$ and the $\operatorname{dog}^{8}$

Nursing problems in the Recovery Room and the incidence of awareness during operation that one might expect from a nitrous oxide-relaxant-fentanyl-naloxone technique have not been previously studied. This study was designed to assess these factors and also ascertain patient acceptance of this anaesthetic technique.

\section{Methods}

The ninety-nine patients were consenting adults undergoing a variety of surgical procedures. All were anaesthetized with a thiopentone-nitrous-oxide-fentanyl-relaxant tech-

J.G. Purdell-Lewis, M.B., F.R.C.P.(C), Department of Anaesthesia; D.M. Blair, B.Sc. Pharmacy, Resident, Department of Pharmacy; and C.A. McLeod, B.Sc. Pharmacy, Resident, Department of Pharmacy, University of Alberta Hospital, Edmonton, Alberta, T6C 2B6.

Mailing Address: Dr. J.G. Purdell-Lewis, Department of Anaesthesia, University of Alberta Hospital, Edmonton, Alberta, T6G 2B6.

Canad. Anaesth. Soc. J., vol. 28, no. 1, January 1981 nique. They were randomly allocated to three equal sized groups: Group I patients received naloxone $0.1 \mathrm{mg}$ intravenously at the end of anaesthesia, Group II patients received naloxone $0.2 \mathrm{mg}$ intravenously and Group III patients received naloxone $0.4 \mathrm{mg}$ intravenously. Complete details of the anaesthetic technique are found in a previous publication. ${ }^{6}$

In the Operating Room, after reversal of residual neuromuscular blockade and ventilation with 100 per cent oxygen for five minutes, observations were made before and two minutes after the administration of naloxone, as listed in Table I.

Observations in the Recovery Room, as listed in Table III were graded and recorded by the nurse responsible for the care of each patient.

Operative awareness and remembrance was investigated in two ways. Firstly, as part of a scheduled post-operative visit by interviewers (D.M.B. and C.A.M.), the patients were asked whether they had memory of any operative events. Secondly, immediately after induction and tracheal intubation, all patients in the study were fitted with a pair of headphones and half of each group (17/33) were exposed to classical or light music throughout the operation. No music was played to the others. The same interviewers asked the patients about recall of music.

The postoperative visit within the first two 
TABLE I

\begin{tabular}{lll}
\hline \multicolumn{1}{c}{ Observation } & \multicolumn{1}{c}{ Classification } & \multicolumn{1}{c}{ Notes } \\
\hline Response to Stimulus & $\begin{array}{l}\text { 1. Severe } \\
\text { 2. Moderate }\end{array}$ & $\begin{array}{l}\text { Stimulus: Peripheral Nerve } \\
\text { Stimulator excitation of } \\
\text { ulnar nerve at elbow. }\end{array}$ \\
& $\begin{array}{l}\text { 4. None } \\
\text { Level of Consciousness }\end{array}$ & $\begin{array}{l}\text { 1. Awakc } \\
\text { 2. Somnolent }\end{array}$ \\
& $\begin{array}{l}\text { 3. Unconscious } \\
\text { (responds to stimulus) }\end{array}$ & See above \\
& 4. Unconscious \\
& (no response to stimulus) & See above \\
\hline
\end{tabular}

TABLE II

\begin{tabular}{|c|c|c|c|c|c|c|c|}
\hline \multirow[b]{2}{*}{ Category } & \multicolumn{2}{|c|}{$\begin{array}{c}\text { Group I } \\
\text { Naloxone } \\
0.1 \mathrm{mg}\end{array}$} & \multicolumn{2}{|c|}{$\begin{array}{c}\text { Group II } \\
\text { Naloxone } \\
0.2 \mathrm{mg}\end{array}$} & \multicolumn{2}{|c|}{$\begin{array}{c}\text { Group III } \\
\text { Naloxone } \\
0.4 \mathrm{mg}\end{array}$} & \multirow[b]{2}{*}{ Note: } \\
\hline & Pre & Post & Pre & Post & Pre & Post & \\
\hline \multicolumn{8}{|l|}{ Level of Consciousness: } \\
\hline Awake & 2.0 & 20.2 & 5.1 & 30.3 & 8.1 & 29.3 & 1,2 \\
\hline Somnolent & 13.1 & 13.1 & 15.2 & 3.0 & 12.1 & 4.0 & 4 \\
\hline Unconscious: response to stimuli & 3.0 & 0.0 & 2.0 & 0.0 & 5.1 & 0.0 & \\
\hline Unconscious: no response to stimuli & 15.2 & 0.0 & 11.1 & 0.0 & 8.1 & 0.0 & \\
\hline \multicolumn{8}{|l|}{ Response to Stimuli: } \\
\hline Severe & 0.0 & 2.0 & 0.0 & 3.0 & 1.0 & 3.0 & 1,3 , \\
\hline Moderate & 0.0 & 10.1 & 6.1 & 23.2 & 3.0 & 22.2 & 4 \\
\hline Mild & 12.1 & 16.2 & 12.1 & 6.1 & 15.2 & 8.1 & \\
\hline None & 21.2 & 5.1 & 15.2 & 1.0 & 14.1 & 0.0 & \\
\hline
\end{tabular}

Notes: All figures given in percentages for a total of 100 in each category, pre-naloxone and post-naloxone.

1. No significant difference among the Groups pre-naloxone.

2. Significant difference between Group I and Groups II and III post-naloxone $(P<0.005)$.

3. Significant difference between Group I and Group III post-naloxone $(P=0.005)$.

4. Significant post-pre-naloxone change (all Groups) $(\mathrm{P}<0.001)$.

days also inquired into the last event before induction of anaesthesia, dreaming, first memory on awakening and willingness to accept this type of anaesthesia again (Table III).

The significance of our results was determined by Chi-square and Student's t-test for matching pairs and was considered significant at $\mathrm{p} 0.05$ or less.

\section{RESULTS}

The range of operative procedures was similar in all three groups and there was no significant difference between the Groups for weight, habitus, sex distribution, duration of anaesthesia, $\mathrm{Pa}_{\mathrm{CO}_{2}}$, or fentanyl dosage. Group I patients were significantly older than those in Group III. Mean weight was $66 \mathrm{~kg}$ and the fentanyl dosage was a mean of $3.3 \mu \mathrm{g} \cdot \mathrm{kg}^{-1} \cdot \mathrm{hr}^{-1}$ and overall mean fentanyl dose was $5.8 \mu \mathrm{g} \cdot \mathrm{kg}^{-1}$. $^{6}$

Level of Consciousness and Response to Stimuli. The administration of naloxone was associated with a significant change toward wakefulness in all Groups, this change being significantly greater in Groups II and III compared with Group I. Similarly the response to stimuli significantly increased in all Groups after the administration of naloxone and the changes in Groups II and III were significantly greater than those in Group I (Table II).

Recovery Room. There was no significant difference among the Groups with respect to shivering, nausea and vomiting, or pain. There was a trend to increased expression of pain in Group III and nearly twice as many patients in this group received analgesics compared to Groups I and II 
TABLE III

\begin{tabular}{|c|c|c|c|}
\hline Category & $\begin{array}{c}\text { Group I } \\
\text { Naloxone } \\
0.1 \mathrm{mg}\end{array}$ & $\begin{array}{c}\text { Group II } \\
\text { Naloxone } \\
0.2 \mathrm{mg}\end{array}$ & $\begin{array}{c}\text { Group IIl } \\
\text { Naloxone } \\
0.4 \mathrm{mg}\end{array}$ \\
\hline \multicolumn{4}{|l|}{$\begin{array}{l}\text { Recovery Room: } \\
\text { Shivering: }\end{array}$} \\
\hline Nil & 26.3 & 20.2 & 19.2 \\
\hline Minimal & 6.1 & 9.1 & 11.1 \\
\hline Major & 0.0 & 4.0 & 3.0 \\
\hline Sustained & 1.0 & 0.0 & 0.0 \\
\hline \multicolumn{4}{|l|}{ Nausea and Vomiting: } \\
\hline Nil & 22.2 & 22.2 & 16.2 \\
\hline Nausea & 3.0 & 7.1 & 5.1 \\
\hline Retching & 0.0 & 0.0 & 2.0 \\
\hline Vomiting & 8.1 & 4.0 & 10.1 \\
\hline \multicolumn{4}{|l|}{ Pain: } \\
\hline Nil & 5.1 & 9.1 & 2.0 \\
\hline Minor & 14.1 & 9.1 & 9.1 \\
\hline Moderate & 2.0 & 5.1 & 4.0 \\
\hline Analgesic required & 12.1 & 10.1 & 18.2 \\
\hline \multicolumn{4}{|c|}{$\begin{array}{l}\text { Post-Operative Inquiry: } \\
\text { Last Memory Pre-Induction: }\end{array}$} \\
\hline Pre I.V. Line & 6.2 & 13.4 & 4.1 \\
\hline Post I.V. Line & 25.2 & 20.6 & 29.9 \\
\hline \multicolumn{4}{|l|}{ Music Heard: } \\
\hline Yes & 0.0 & 0.0 & 0.0 \\
\hline No & 26.4 & 32.1 & 34.0 \\
\hline Possible & 5.7 & 1.8 & 0.0 \\
\hline \multicolumn{4}{|c|}{ Memory of Operative Events: } \\
\hline Yes & 1.0 & 0.0 & 0.0 \\
\hline No & 30.9 & 34.0 & 33.0 \\
\hline Possible & 0.0 & 0.0 & 1.0 \\
\hline \multicolumn{4}{|l|}{ Dreaming: } \\
\hline Yes & 1.0 & 3.1 & 4.1 \\
\hline No & 30.9 & 30.9 & 29.9 \\
\hline \multicolumn{4}{|c|}{ First Memory on Awakening: } \\
\hline Opcrating Room & 3.1 & 2.1 & 8.2 \\
\hline Recovery Room & 17.5 & 20.6 & 14.4 \\
\hline Ward & 11.3 & 11.3 & 11.3 \\
\hline \multicolumn{4}{|c|}{ Acceptance of this Anaesthesia: } \\
\hline Yes & 20.6 & 21.6 & 21.6 \\
\hline Don't Mind & 9.3 & 9.4 & 10.3 \\
\hline No & 2.1 & 3.0 & 2.1 \\
\hline
\end{tabular}

1. All figures given in percentages for a total of 100 in each category.

2. No significant difference among the Groups.

(Table III). The study design did not incorporate a score for restlessness, but an incidental observation by some nurses was that some patients were particularly restless and this appeared to be associated with the naloxone $0.4 \mathrm{mg}$ dosage.

Operative Awareness and Recall. Only one patient remembered, and one other patient might have remembered part of the surgical procedure. The incidence of awareness and recall is therefore between one and two per cent.

Examination of awareness and recall of the musical stimulus shows that none of the patients in the non-music control group thought they had heard music. Of those who were exposed to it none definitely remembered it whilst 7.5 per cent (four patients) thought they heard music.

The patient with true awareness was provided with music, but had no recollection of it, while the patient with possible awareness was in the no music group.

There was no relationship between operative awareness and recall on the one hand and naloxone dosage on the other.

Last Memory Before Induction. The naloxone 
TABLE IV

\begin{tabular}{lccc}
\hline \hline & Group I & Group II & Group III \\
\hline $\begin{array}{l}\text { Nausea and Vomiting } \\
\begin{array}{l}\text { Little sedation/euphoria } \\
\text { with Diazepam premedications }\end{array}\end{array}$ & 1 & 1 & 2 \\
Slow awakening in Recovery Room & 1 & & 1 \\
\hline
\end{tabular}

dosage had no effect on the last memory before induction, and a total of 76 per cent of the patients remembered events after insertion of the intravenous line.

Dreaming at some time during anaesthesia was reported by eight patients ( 8.2 per cent). There was a statistically insignificant relationship between the naloxone dosage and recollection of dreaming, the highest incidence being in the Group of patients which received naloxone $0.4 \mathrm{mg}$.

First Memory on Awakening. Overall 13.4 per cent of patients first remembered the Operating Room; a further 52.5 per cent first remembered the Recovery Room and the remaining 34.1 per cent first remembered the Ward. There was a non-significant trend for patients in Group III to have first memory of the Operating Room rather than the Recovery Room.

Recovery Room Stay was 50 minutes on the average, with no significant difference amongst the Groups.

Preference for Anaesthesia. In 92.8 per cent of instances patients would either positively prefer or would not mind this type of anaesthesia again. The remaining 7.2 per cent ( 7 patients) would not like this anaesthesia again for reasons stated in Table IV.

\section{Discussion}

A variety of reports have attested to the speed and effectiveness of naloxone in reversing the respiratory depressant effects of fentanyl and in restoring wakefulness. ${ }^{2-4,9,10}$ This study confirms that naloxone raises the level of consciousness significantly and enhances the response to stimuli. Our results show a relationship between naloxone dosage and response, the effect being maximal with naloxone $0.2 \mathrm{mg} / 66 \mathrm{~kg}$. This is in accord with the finding of Tigerstedt. ${ }^{9}$

In the Recovery Room the different doses of naloxone did not affect the incidence of shivering, nausea and vomiting or pain; with regard to pain these results are at variance with those of Tigerstedt ${ }^{5.9}$ who found a relationship between increasing pain and increasing naloxone dosage. We found that 40.4 per cent of our patients required analgesia in the Recovery Room, which does not accord with the results of Andersen et $a l .{ }^{3}$ whose patients treated with naloxone had no need of additional analgesics during the first $5 \frac{3}{4}$ postoperative hours; this difference may be due to the fact that Andersen's patients reccived droperidol as part of the anaesthetic sequence.

The investigation of awareness and dreaming during anaesthesia and operation and the separation of the two is a complex problem which has been addressed by several authors. ${ }^{1-16}$ In this study we chose to expose patients to a continuous musical stimulus and found no definite awareness. There was a possible incidence of 7.5 per cent of awareness to music and a definite operative awareness in one patient; this compares with an awareness incidence of zero reported by Browne et al. " who used Innovar , five per cent reported by McKie et al..$^{14}$ in a paediatric hospital and four per cent reported by Barr et al. ${ }^{13}$ Our incidence of dreaming was 8.2 per cent which contrasts with a 44 per cent incidence reported by Brice et al. ${ }^{12}$ and zero by Browne et al. ${ }^{11}$ These findings would suggest that the fentanyl dosage of $1.5 \mu \mathrm{g} \cdot \mathrm{kg}^{-1}$ every 30 minutes used in this present study could be inadequate and a technique involving the use of a loading dose of fentanyl would be more appropriate.

This study showed a high degree of patient acceptance of fentanyl-supplemented anaesthesia. Many commented on the early, relatively pain-free awakening and only five patients (five per cent) in the study complained of slow awakening or nausea and vomiting. This compares favourably with the report of Cronin et al. ${ }^{17}$ who found that 12 per cent of their patients complained of nausea and vomiting, using rating criteria similar to ours.

\section{ACKNOWLEDGEMENTS}

The authors are indebted to Mrs. R.D. Sagert and Mrs. F.R. Smith for secretarial assistance and to Endo Laboratories, Inc. and McNeil 
Laboratories (Canada) Ltd. for generous financial assistance.

\section{REFERENCES}

1. Personal Communication, Department of Pharmacy, University of Alberta Hospital.

2. Arner, S. \& Gordon, E. The antagonistic effect of naloxone $\mathrm{HCl}$ after neurolept-anaesthesia during neurosurgery. Acta anaesth. scand. 20:201 (1976).

3. Andersen, R., Dobloug, L. \& Refstad, S. Postanaesthetic use of naloxone $\mathrm{HCl}$ after moderate doses of fentanyl. Acta anaesth. scand. 20: 255 (1976).

4. Tigerstedt, I. Antagonism of fentanyl with naloxone during $\mathrm{N}_{2} \mathrm{O}+\mathrm{O}_{2}+$ halothane anaesthesia. Acta anaesth. scand. 21: 470 (1977).

5. Tigerstedt, I. Reversal of fentanyl induced narcotic depression with naloxone following general anaesthesia. Acta anaesth. scand. 22: 234 (1978).

6. Purdell-Lewis, J.G. Studies in fentanylsupplemented anaesthesia: effect of naloxone on the circulation and respiration. Canad. Anaesth. Soc. J. 27: 323 (1980).

7. Desmonts, J.M., Bohm, G. \& Couderc, E. Hemodynamic responses to low doses of naloxone after narcotic-nitrous oxide anaesthesia. Anesthesiology 49: 12 (1978).

8. Schweichel, E., Schmidt, D., Schneider, E. \& BruCKNER, J.B. Circulatory pattern and duration of action of naloxone in dogs with and without opioid pretreatment. Acta anaesth. scand. 23: 336 (1976)
9. Tigerstedt, J. Naloxone as narcotic antagonist after balanced anaesthesia. Acta anaesth. scand. 21: 48 (1977).

10. Dick, W., Milewski, P., Knoche, E. \& Trali, E. Clinical studies on the usefulness of naloxone after shortlasting anaesthesia with narcotic analgesics. der Anaestheist 27: 272 (1978).

11. Browne, R.A. \& Catton, D.V. Awareness during anaesthesia: $A$ comparison of anaesthesia with nitrous oxide-oxygen and nitrous oxide-oxygen with Innovar Canad. Anaesth. Soc. J. 20: 763 (1973).

12. Brice, D.D., Hetherington, R.R. \& Utting, J.E. A simple study of awareness and dreaming during anaesthesia. Brit. J. Anaesth. 42:535 (1970).

13. BARR, A.M. \& Wong, R.M. Awareness during general anaesthesia for bronchoscopy and laryngoscopy using the apnoeic oxygenation technique. Brit. J. Anaesth. 45: 894 (1973).

14. MCKiE, B.D. \& ThORPE, E.A. Awareness and dreaming during anaesthesia in a paediatric hospital. Anaesth. Inten. Care I: 407 (1973).

15. TomLin, P.J. \& Hurten, C. Awareness during anaesthesia (correspondence) Brit. J. Anaesth. 50: 307 (1978)

16. MCINTYRE, J.W.R. Awareness during general anaesthesia: Preliminary observations. Canad. Anaesth. Soc. J. 13: 495 (1966).

17. Cronin, M., Redfern, P.A. \& Utting, J.E. Psychometry and postoperative complaints in surgical patients. Brit. J. Anaesth. 45: 879 (1973).

\section{RÉSUMÉ}

Sans sélection préalable, on a administré une anesthésie générale standardisée au fentanyl $1.5 \mu \mathrm{g} \cdot \mathrm{kg}^{-1}$ injecté aux 30 minutes et on a réparti les patients au hasard en trois groupes égaux; le groupe I a reçu naloxone $0.1 \mathrm{mg}$, le groupe II naloxone $0.2 \mathrm{mg}$ et le groupe III naloxone $0.4 \mathrm{mg}$ par la voie veineuse à la fin de l'intervention après le renversement du bloquage neuro-musculaire. Après la naloxone, le niveau de conscience s'est allégée et la réponse au stimulus s'est amélioré: les changements ont été significatifs pour les trois groupes et ces changements ont été plus marqués de façon significative pour les groupes II et III comparativement au groupe I. A la salle de réveil, on n'a pas noté de différence significative entre les groupes pour le frisson, les nausées, les vomissements et la douleur. L'incidence de conscience per-opératoire a été de un pour cent et celle de rêve de huit pour cent et sans relation avec la dose de naloxone. Le taux d'acceptation par les patients a été élevé. Sept des patients ne désireraient plus ce type d'anesthésie à l'avenir, deux à cause d'une prémédication légère (inhérente à ce type d'étude), deux à cause de nausées et vomissements et un patient à cause d'un réveil trop lent. 